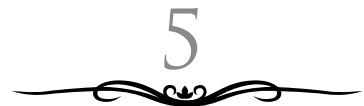

\title{
EKSISTENSI PUSTAKAWAN DALAM PENINGKATAN KUALITAS PERPUSTAKAAN PERGURUAN TINGGI MELALUI AKREDITASI PERPUSTAKAAN
}

\author{
Khusnul Khotimah \\ UIN Sunan Kalijaga Yogyakarta, Indonesia \\ oenoel68@yahoo.co.id
}

\begin{abstract}
Efforts to improve the quality of university libraries should be conducted continuously with reference to library standards published by the National Library. Assessment of the quality of university libraries can be done through accreditation library. Accredited certificate can obtain a university library based on the amount of the weighted value of nine components. These components are the components of the service, collaboration, collection, organizing library materials, human resources, building or space and infrastructure, budget, library management and maintenance of the library collection. To be accredited university library to get the most, librarians should play an active role. Some examples of the role of librarians in the accreditation activities of the university library are studying the accreditation guidelines, prepare the physical evidence, conduct self-evaluation, and perform simulations accreditation.
\end{abstract}

Keywords: University Library, Library Accreditation, Quality library, Role of Librarians. 


\begin{abstract}
Abstrak
Usaha peningkatan kualitas perpustakaan perguruan tinggi harus dilakukan secara terus menerus dengan mengacu pada standar perpustakaan yang diterbitkan oleh Perpustakaan Nasional RI. Kegiatan penilaian terhadap kualitas perpustakaan perguruan tinggi dapat dilakukan melalui akreditasi perpustakaan. Sertifikat terakreditasi dapat diperoleh suatu perpustakaan perguruan tinggi berdasarkan jumlah nilai tertimbang dari sembilan komponen. Komponen-komponen tersebut adalah komponen layanan, kerjasama, koleksi, pengorganisasian bahan perpustakaan, sumber daya manusia, gedung atau ruang dan sarana prasarana, anggaran, manajemen perpustakaan dan perawatan koleksi perpustakaan. Agar akreditasi perpustakaan perguruan tinggi mendapatkan hasil maksimal, pustakawan harus berperan aktif. Beberapa contoh dari peran pustakawan dalam kegiatan akreditasi perpustakaan perguruan tinggi adalah mempelajari pedoman akreditasi, menyiapkan bukti-bukti fisik, melakukan evaluasi diri, dan melakukan simulasi akreditasi.
\end{abstract}

Kata Kunci: Perpustakaan Perguruan Tinggi, Akreditasi Perpustakaan, Kualitas Perpustakaan, Peran Pustakawan.

\title{
A. Pendahuluan
}

Sudah menjadi semboyan yang dipahami bersama oleh masyarakat umum bahwa perpustakaan adalah jantung suatu perguruan tinggi (the heart of a university). ${ }^{1}$ Semboyan tersebut dapat dimaknai bahwa perpustakaan perguruan tinggi merupakan pusat belajar mengajar (center for learning and instruction). Sebagai lembaga yang menjadi pusat dan urat nadi pendidikan, kedudukan perpustakaan perguruan tinggi menempati posisi yang sangat penting dan strategis. Jika diperhatikan, setiap lembaga perguruan tinggi di manapun, hampir dapat dipastikan tentu telah mempunyai perpustakaan. Bahkan, ketika sebagian besar perguruan tinggi menawarkan dan mempromosikan lembaganya

1 Peter Brophy, The Academic Library (London: Facet Publishing, 2006), hlm. 1. 
ke seluruh lapisan masyarakat, biasanya mereka menyertakan keberadaan perpustakaan sebagai salah satu aset penting yang dimilikinya. Perpustakaan perguruan tinggi dianggap sebagai aset penting karena menjadi pusat informasi, pusat pendidikan dan pengajaran, pusat penelitian, dan berbagai sebutan penting lainnya untuk kepentingan sivitas akademika. Hanya saja, meskipun setiap lembaga perguruan tinggi telah mempunyai perpustakaan, akan tetapi tidak semua perpustakaan yang dimilikinya itu mempunyai standar kualitas yang tinggi.

Padahal, agar perpustakaan perguruan tinggi benar-benar dapat diwujudkan sebagai pusat pendidikan, pusat penelitian, dan pusat pengabdian masyarakat bagi sivitas akademikanya atau yang dikenal dengan istilah tri dharma perguruan tinggi, maka perpustakaan tersebut harus dikelola dengan memperhatikan prinsip-prinsip kualitasnya. Konsep kualitas itu sendiri sering dianggap sebagai ukuran relatif kebaikan dari suatu produk atau jasa yang terdiri atas kualitas desain dan kualitas kesesuaian. ${ }^{2}$ Kualitas desain merupakan fungsi spesifikasi produk dan jasa, sedangkan kualitas kesesuaian merupakan suatu ukuran seberapa jauh suatu produk dan jasa tersebut dapat memenuhi persyaratan atau spesifikasi kualitas yang telah ditetapkan. Meskipun demikian, kualitas tidak hanya menekankan pada aspek hasilnya saja, melainkan juga pada kualitas manusia dan kualitas prosesnya. Kualitas dapat dikatakan ada, apabila sebuah produk atau sebuah jasa memnuhi spesifikasi yang ada.

Bagi setiap lembaga, tidak terkecuali lembaga perpustakaan perguruan tinggi, kualitas adalah agenda utama, dan meningkatkan kualitas merupakan tugas yang paling penting. ${ }^{3}$ Walaupun demikian, ada sebagian orang yang menganggap kualitas sebagai sebuah konsep yang penuh dengan teka-teki. Kualitas dianggap sebagai suatu hal yang sangat membingungkan dan sulit diukur.

${ }^{2}$ Fandy Tjiptono dan Anastasia Diana, Total Quality Management (Yogyakarta: Penerbit Andi, 2003), hlm. 2.

${ }^{3}$ Edward Sallis, Total Quality Management in Education: Manajemen Mutu Pendidikan (Yogyakarta: IRCiSoD, 2006), hlm. 29. 
Kualitas dalam pandangan seseorang terkadang bertentangan dengan kualitas dalam pandangan orang lain, sehingga tidak aneh jika terdapat perbedaan di antara para pakar tentang bagaimana cara menciptakan kualitas institusi yang baik.

Goetsch dan Davis pernah membuat definisi tentang kualitas sebagai suatu kondisi dinamis yang berhubungan dengan produk, jasa, manusia, proses, dan lingkungan yang memenuhi atau melebihi harapan. ${ }^{4}$ Dari definisi tersebut dapat dilihat bahwa kualitas meliputi tiga aspek, yaitu: (1) usaha memenuhi atau melebihi harapan seseorang; (2) kualitas mencakup produk, jasa, manusia, proses, dan lingkungan; dan (3) kualitas merupakan kondisi yang selalu berubah, artinya apa yang dianggap merupakan kualitas saat ini, mungkin dianggap kurang berkualitas pada masa mendatang.

Kualitas perpustakaan perguruan tinggi sebagai lembaga penyedia dan pemberi jasa lebih sulit untuk didefinisikan dari pada kualitas produk, karena karakteristik kualitas jasa mencakup beberapa elemen subjek yang penting. Jasa tidak dapat dipisahkan antara orang yang memberi jasa dengan orang yang menerima jasa. Dengan demikian, pustakawan sebagai pemberi jasa tentu harus berperan secara aktif dan mampu memberikan kesan dan citra yang baik di mata pemustaka sebagai pihak penerima jasa. Hubungan antara pustakawan dan pemustaka harus benarbenar terjalin secara harmonis karena kualitas jasa ditentukan oleh keduanya.

Meskipun konsep tentang kualitas jasa tersebut cukup membingungkan dan memiliki perbedaan persepsi antara satu orang dengan lainnya, tidak berarti bahwa perpustakaan perguruan tinggi tersebut harus mengabaikan begitu saja dan tidak memperdulikan konsep kualitas lembaganya. Dengan kata lain, upaya peningkatan kualitas perpustakaan perguruan tinggi harus tetap diusahakan. Salah satu cara dalam peningkatan

${ }^{4}$ D.L. Goetsch and S. David, Introduction to Total Quality: Quality, Productivity, Competitiveness (Englewood Cliffs, NJ: Prentice Hall International, 1994), hlm. 4. 
kualitas perpustakaan adalah dengan melakukan evaluasi secara terus menerus. Komite Studi Nasional dari UCLA menyatakan bahwa evaluasi merupakan suatu proses atau kegiatan pemilihan, pengumpulan, analisis, dan penyajian informasi yang dapat digunakan sebagai dasar pengambilan keputusan serta penyusunan program selanjutnya. ${ }^{5}$ Evaluasi tersebut dapat dilakukan secara internal dengan mengacu kepada standar yang telah ditentukan dan disepakati bersama. Standar tersebut dapat berskala nasional maupun internasional. Misalnya di Indonesia sudah ada Standar Nasional Indonesia yang dikeluarkan oleh Badan Standar Nasional dan Standar Nasional Perpustakaan yang dikeluarkan oleh Perpustakaan Nasional. Karena kedua standar tersebut sifatnya minimal, maka indikator-indikator yang dijadikan dasar evaluasi perpustakaan harus terlampaui agar perpustakaan tersebut memiliki kualitas yang lebih dari sekedar memenuhi standar yang ada.

Kemudian, setelah evaluasi internal telah dilakukan dan sekiranya sudah merasa cukup sesuai bahkan melampaui dengan standar yang ada, maka perpustakaan perguruan tinggi tersebut dapat mengajukan akreditasi ke lembaga yang berwenang. Hal tersebut seperti yang telah diamanatkan dalam UU No. 43 Tahun 2007 Tentang Perpustakaan yang menyebutkan bahwa semua perpustakaan perguruan tinggi dalam pengelolaannya seharusnya memenuhi Standar Nasional Perpustakaan Nomor 010 Tahun 2011. Agar semua perguruan tinggi menjalankan amanah UU dan dalam pengelolan perpustakaannya memenuhi Standar Nasional Perpustakaan, maka alangkah baiknya jika semua perpustakaan di lingkungan perguruan tinggi diwajibkan untuk akreditasi. Hal ini tentunya akan berdampak sangat positif terhadap perguruan tinggi, perpustakaan dan sivitas akademika.

Akreditasi merupakan hal yang sangat penting, karena yang melakukan akreditasi terhadap perpustakaan perguruan tinggi tersebutbiasanya adalah orang-orang ahli dariluar lembaga. Tujuan

5 J.S. Stark and A. Thomas, Assesment and Program Evaluation (California: Simon and Schuster Custom Publishing, 1994), hlm. 4. 
dari akreditasi perpustakaan secara umum adalah memberikan penilaian yang objektif, transparan dan berkelanjutan terhadap pelayanan suatu perpustakaan berdasarkan kriteria-kriteria yang telah ditetapkan. Dengan demikian akreditasi yang berhasil akan menunjukkan kepada masyarakat bahwa kualitas perpustakaan tersebut tidak hanya diakui oleh orang dalam saja, tetapi juga diakui oleh orang luar lembaganya. Untuk mewujudkan hal tersebut, setiap perpustakaan perguruan tinggi hendaknya mempersiapkan segala perangkat yang diperlukan dalam akreditasi. Tentu saja persiapan-persiapan tersebut harus dilakukan oleh pustakawan sebagai pengelola utama sebuah perpustakaan. Di sinilah peran pustakawan menjadi sangat diperlukan. Dengan demikian, para pustakawan tidak hanya bertugas melayani pemustaka dan tugas-tugas rutin lainnya, tetapi mereka harus terampil dan ahli dalam mempersiapkan segala hal yang berhubungan dengan akreditasi perpustakaan. Di samping itu, pustakawan harus mempelajari borang akreditasi dengan cermat, memperhatikan komponen dan indikator-indikator penilaian dalam akreditasi dengan teliti. Semuanya itu dilakukan agar perpustakaan yang dikelolanya mendapatkan nilai akreditasi yang tinggi. Misalnya komponen layanan, kerja sama, koleksi, pengorganisasian bahan perpustakaan, sumber daya manusia, gedung, ruang, sarana prasarana, anggaran, manajemen perpustakaan, dan perawatan koleksi perpustakaan.

Nilai akreditasi yang tinggi yang diberikan oleh Perpustakaan Nasional dan Badan Akreditasi Nasional Perguruan Tinggi dapat menjadi jaminan bahwa perpustakaan perguruan tinggi tersebut telah dikelola dengan kualitas yang baik. Keadaan ini tentu saja dapat meningkatkan kepercayaan terhadap lembaganya, baik kepercayaan dari pimpinan lembaga induknya maupun kepercayaan dari masyarakat secara luas. Inilah di antara pentingnya perpustakaan perguruan tinggi diikutkan dalam akreditasi perpustakaan. Dengan demikian, perpustakaan perguruan tinggi tersebut dapat mengetahui kualitas lembaganya dan secara terus-menerus akan melakukan upaya perbaikan. 
Inilah mengapa dikatakan bahwa salah satu tujuan akreditasi adalah memperbaiki lembaga yang diakreditasi. ${ }^{6}$

Berdasarkan latar belakang di atas tersebut itulah tulisan ini disusun dengan tujuan untuk memaparkan pentingnya akreditasi perpustakaan perguruan tinggi dalam rangka pengingkatan kualitas perpustakaan. Harapan penulis tentu saja dapat ikut serta memberikan motivasi kepada para pengelola perpustakaan perguruan tinggi agar dapat mengikuti program akreditasi perpustakaan, sehingga mengetahui standar perpustakaan yang dikelolanya.

\section{B. Pembahasan}

\section{Kualitas Perpustakaan Perguruan Tinggi}

Perpustakaan sebagaimana yang ada dan berkembang saat ini berfungsi sebagai salah satu pusat informasi, sumber ilmu pengetahuan, penelitian, pendidikan, rekreasi, pelestari khazanah budaya bangsa serta berbagai jenis jasalayanan yang diperuntukkan bagi pemustaka. ${ }^{7}$ Fungsi-fungsi tersebut bersifat umum, artinya seluruh perpustakaan apapun jenisnya tentu berfungsi demikian, termasuk juga perpustakaan perguruan tinggi. Perpustakaan perguruan tinggi, perpustakaan universitas, yang juga terkadang disebut perpustakaan akademis sering dianggap sebagai sumber informasi yang paling penting bagi sebuah perguruan tinggi yang menjadi lembaga induknya. Sebagai salah satu institusi kultural yang paling berharga, perpustakaan perguruan tinggi pusat penyedia informasi dan pelayanan yang sangat penting bagi proses belajar dan mengajar sivitas akademika.

6 Dewi Puspitasari, "Penjaminan Mutu Perpustakaan Perguruan Tinggi”, Jurnal Perpustakaaan Airlangga (JPUA), Vol. 5, No. 1, Januari-Juni 2015, hlm. 8 .

${ }^{7}$ Sutarno NS, Perpustakaan dan Masyarakat (Jakarta: Yayasan Obor Indonesia, 2003), hlm. 1. Lihat juga Sulistyo Basuki, Pengantar Ilmu Perpustakaa (Jakarta: Gramedia, 1993), hlm. 6-7. 
Menurut Undang-undang Nomor 43 Tahun 2007 Tentang Perpustakaan dalam Bab I Pasal 1 ayat (1) disebutkan bawah perpustakaan adalah institusi pengelola karya tulis, karya cetak dan/atau karya rekam secara profesional dengan sistem baku guna memenuhi kebutuhan pendidikan, penelitian, pelestarian, informasi, dan rekreasi para pemustaka. Adapun yang menjadi dasar akreditasi perpustakaan perguruan tinggi adalah dalam Pasal 18 UU No. 43 Tahun 2007 yang berbunyi "setiap perpustakaan dikelola sesuai dengan standar nasional perpustakaan”. Selanjutnya dalam Pasal 24 ayat (1) dinyatakan bahwa "setiap perguruan tinggi menyelenggarakan perpustakaan yang memenuhi standar nasional perpustakaan dengan memperhatikan Standar Nasional Pendidikan".

Seperti yang diamanatkan dalam UU No. 43 Tahun 2007 Tentang Perpustakaan yang menyebutkan bahwa semua perpustakaan perguruan tinggi dalam pengelolaannya seharusnya memenuhi Standar Nasional Perpustakaan Nomor 010 Tahun 2011. Agar semua perpustakaan perguruan tinggi menjalankan amanah undang-undang tersebut dan dalam pengelolan perpustakaannya memenuhi Standar Nasional Perpustakaan, maka alangkah baiknya jika semua perpustakaan di lingkungan perguruan tinggi diwajibkan untuk mengikuti akreditasi. Hal ini tentunya akan berdampak sangat positif terhadap perguruan tinggi, perpustakaan dan sivitas akademikanya.

Menurut Sulistyo Basuki, tugas perpustakaan perguruan tinggi di antaranya adalah: (a) melaksanakan pemilihan bahan perpustakaan yang sesuai dengan kebutuhan sivitas akademika yang membutuhkan informasi; (b) mengolah bahan perpustakaan sehingga mudah ditemukan dan dipergunakan oleh pemustaka; (c) menyelenggarakan peminjaman bahan perpustakaan dengan cara yang efisien; (d) memberikan bimbingan kepada pemustaka dalam memanfaatkan perpustakaan; dan (e) menyelenggarakan kerja sama dengan memanfaatkan jaringan informasi. ${ }^{8}$

8 Sulistyo Basuki, Periodisasi Perpustakaan Indonesia (Bandung: Remaja Rosdakarya, 1994), hlm. 67. 
Evans, Intner, dan Weihs menjelaskan bahwa pada umumnya perpustakaan mempunyai sembilan fungsi dasar, yaitu: (a) mengidentifikasi informasi yang secara potensial bisa dimasukkan ke dalam koleksi perpustakaan; (b) melakukan seleksi terhadap informasi yang telah diidentifikasi yang sesuai dengan kebutuhan; (c) melakukan akuisisi agar koleksi yang telah terpilih itu dapat dimasukkan ke dalam koleksi perpustakaan; (d) melakukan organisasi informasi agar informasi yang dibutuhkan pemustaka dapat ditemukan lokasinya dengan mudah; (e) melakukan penyiapan agar sumber informasi mudah disimpan dan ditemukan kembali pada saat dibutuhkan; (f) mengatur penyimpanan sumber informasi sehingga mudah digunakan dan tidak mudah mengalami kerusakan; (g) melakukan interpretasi terhadap kebutuhan informasi pemustaka dengan cara melakukan penerjamahan ke dalam bahasa indeks, menterjemahkan kebutuhan informasi pemustaka, dan melakukan bimbingan baik secara langsung maupun tidak langsung; (h) melakukan pengembangan secara terus menerus dengan menyediakan tempat dan fasilitas yang dapat digunakan untuk memberikan pelayaan yang efektif; dan (i) melakukan diseminasi informasi dengan membangun sistem yang mudah digunakan. ${ }^{9}$

Namun sayangnya, perpustakaan akademis saat ini sedang menghadapi tantangan terbesarnya yaitu sejak munculnya jaringan internet dan banyaknya informasi virtual yang juga ditunjang dengan perpustakaan virtual. ${ }^{10} \mathrm{Hal}$ ini mendatangkan banyak pertanyaan mengenai peran dan masa depan perpustakaan akademis. Bagaimana perpustakaan mempertahankan dan memperkuat citranya serta mengerahkan segala sumber daya yang dimiliki untuk memenuhi harapan pemustaka adalah satu

${ }^{9}$ G. Edward Evans, Sheila S. Intner, and Jean Weihs, Introduction To Technical Services (California: Libraries Unlimited, 2011), hlm. 7.

10 Perpustakaan virtual (virtual library), disebut demikian karena informasi dapat diakses dari jarak jauh tanpa membutuhkan perpustakaan secara fisik. Penjelasan ini dapat dilihat di Richard E. Rubin, Foundations of Library and Information Science (New York: Neal-Schuman Publishers, 1998), hlm. 57. 
satunya cara agar perpustakaan akademis tersebut dapat bertahan dalam lingkungan yang terus berubah dan tidak terduga ini. Untuk itu, perpustakaan perguruan tinggi sebagai pusat informasi bagi sivitas akademika harus mampu membantu ketika mereka membutuhkan informasi dengan efektif dan efisien. Perpustakaan tidak boleh berlaku pasif terhadap kebutuhan informasi sivitas akademikanya. Perpustakaan harus membuat berbagai inovasi agar sivitas akademika tetap memiliki loyalitas yang tinggi terhadap perpustakaan.

Hal tersebut dilakukan agar perpustakaan perguruan tinggi tidak ditinggalkan sivitas akademika sebagai penggunanya. Di samping itu, kualitas perpustakaan harus secara terus menerus ditingkatkan, baik dari aspek fisiknya maupun dari aspek pelayanannya. Karena perpustakaan merupakan lembaga pelayanan, maka yang ditingkatkan tentu saja diprioritaskan pada kualitas pelayanannya. Kualitas pelayanan dapat dimaknai sebagai sebuah kata yang bagi penyedia jasa merupakan sesuatu yang harus dikerjakan dengan baik. ${ }^{11}$

Adapun menurut Gronroos, sebagaimana dikutip oleh Ratminto dan Winarsih, definisi pelayanan adalah suatu aktivitas atau serangkaian aktivitas yang bersifat tidak kasat mata yang terjadi sebagai akibat adanya interaksi antara konsumen dengan karyawan atau hal-hal lain yang disediakan oleh perusahaan pemberi pelayanan yang dimaksud untuk memecahkan permasalahan konsumen atau pelanggan. ${ }^{12}$ Jika pendapat ini diterapkan di perpustakaan perguruan tinggi, maka pelayanan perpustakaan adalah serangkaian kegiatan perpustakaan yang tidak kasat mata yang terjadi sebagai akibat adanya interaksi antara pustakawan dengan pemustaka yang dilayaninya.

Perpustakaan perguruan tinggi dikatakan baik dan berkualitas jika dapat memenuhi beberapa kriteria, antara lain

11 J. Supranto, Pengukuran Tingkat Kepuasan Pelanggan, Cetakan Ketiga (Jakarta: Rineka Cipta: Jakarta, 2006), hlm. 226.

${ }^{12}$ Ratminto dan Atik Winarsih, Manajemen Pelayanan (Yogyakarta: Pustaka Pelajar, 2005), hlm. 2. 
adalah: (a) sumber daya manusia yang berkualitas dan profesional; (b) koleksi yang relevan dan aktual; (c) sistem pelayanan yang baik dan berkualitas; serta (d) didukung oleh sarana dan prasarana yang memadai. Hernon dan Altman menambahkan bahwa perpustakaan yang baik adalah perpustakaan yang mampu memberikan pelayanan sesuai dengan kebutuhan masyarakat penggunanya. ${ }^{13}$ Untuk mewujudkan hal tersebut perlu disusun kebijakan pelayanan yang dapat dijadikan sebagai dasar dan acuan bagi para pengelola perpustakaan perguruan tinggi. ${ }^{14}$

Selanjutnya, seperti yang telah dijelaskan pada bagian awal, perpustakaan perguruan tinggi sebagai lembaga publik, salah satu fungsinya adalah menyediakan pelayanan kepada masyarakat penggunanya (service provider). Menurut Hughes, pada era 1980 hingga 1990-an, terdapat perubahan nuansa pelayanan publik dari bentuk yang hirarki dan kaku ke arah sistem yang lebih fleksibel dan berorientasi pasar. ${ }^{15}$ Orientasi pasar yang dimaksudkan adalah adanya keseimbangan antara posisi penawaran (supply) dan permintaan (demand). Penawaran produk (barang ataupun jasa) akan ditentukan oleh permintaan masyarakat atas suatu jenis pelayanan publik. Namun demikian, mekanisme antara penawaran dan permintaan sulit ditentukan posisinya untuk jenis lembaga pelayanan yang berorientasi nirlaba (non profit oriented), seperti perpustakaan perguruan tinggi.

Dengan kata lain, untuk pelayanan perpustakaan perguruan tinggi, masyarakat pengguna tidak mempunyai pilihan lain sebagai pembanding dengan lembaga lain atau tidak ada alternatif lain. Menurut Hughes, birokrasi pemerintah telah memiliki posisi yang kuat (powerful) dalam berkompetisi sehingga kinerjanya terkadang tidak kompetitif. ${ }^{16}$ Konsekuensi logis yang timbul

${ }^{13}$ Peter Hernon and Ellen Altman, Assessing Service Quality: Satisfying The Expectations of Library Customers (Chicago: American Library Assiciation, 1998), hlm. 7.

${ }^{14}$ Ibid.

${ }^{15}$ Owen E. Hughes, Public Management and Administration (London: McMillan, 1994), hlm. 1.

${ }^{16}$ Ibid., hlm. 86. 
dari ketidakkompetitifan kinerja ini dapat terlihat dari perilaku para petugasnya dalam hal pelayanan kepada masyarakat yang cenderung kaku, berbelit-belit dan mengandalkan kekuasaan (power). Keadaan seperti inilah yang membelokkan makna pelayanan dari pemberi layanan (public servants) menjadi yang dilayani (the served). Keadaan seperti ini semestinya harus segera direposisi sehingga dapat mewujudkan suatu pelayanan berkualitas yang sesuai dengan keinginan masyarakat atau berorientasi pada kepuasan pengguna.

Untuk dapat mewujudkan suatu pelayanan yang berkualitas, setiap perpustakaan perguruan tinggi perlu mengiidentifikasi halhal yang menjadi hambatan-hambatan selama ini serta dimensidimensi yang dibutuhkan untuk memperbaikinya. Menurut Hernon dan Altman terdapat beberapa faktor yang perlu dicermati dalam perbaikan kualitas jasa pelayanan perpustakaan, antara lain: (a) ketepatan waktu pelayanan (time lines), yaitu perbandingan antara pelayanan dengan waktu tunggu penyelesaian; (b) akurasi, yaitu berkaitan dengan reliabilitas dan minimalisasi adanya kesalahan-kesalahan; (c) kesopanan dan keramahan petugas dalam memberikan pelayanan; (d) tanggung jawab dari pemberi layanan agar pelayanan berjalan dengan baik dan memuaskan; (e) kelengkapan, yaitu menyangkut kesiapan sarana prasarana pendukung pelayanan; (f) kemudahan, yaitu menyangkut ketersediaan outlet pengguna sehingga pengguna tidak perlu antri panjang dalam pelayanan, termasuk komputerisasi untuk mempercepat proses; (g) variatif, maksudnya petugas harus mampu berinovasi untuk menciptakan pola-pola pelayanan baru untuk dapat mencegah kemungkinan timbulnya kebosanan; (h) pelayanan khusus/pribadi, yaitu menyangkut pengecualian terhadap pengguna dengan permintaan atau kebutuhan khusus; (i) kenyamanan, yaitu menyangkut lingkungan unit pelayanan yang memberikan ketentraman bagi pengguna. ${ }^{17}$

${ }^{17}$ Peter Hernon and Ellen Altman, Service Quality in Academic Libraries (Norwood, New Jersey: Ablex Pubishing Corporation, 1995), hlm. 51-55. 
Selanjutnya,Zeithaml, Parasuraman, dan Berrymenjelaskan kualitas pelayanan dapat dilihat dari lima dimensi yang terkenal dengan SERVQUAL (Service Quality), yaitu dimensi kualitas yang meliputi tangibles, reliability, responsiveness, assurance, dan empathy. ${ }^{18}$ Tangibles merupakan kemampuan organisasi dan sumber daya manusia dalam memberikan pelayanan yang konkrit sesuai dengan standar yang dijanjikan kepada pelanggan dari segi fisiknya. Reliability adalah kemampuan memberikan pelayanan yang dapat dipercaya oleh pelanggan, misalnya kehandalan pustakawan dalam memberikan pelayanan, dan juga kehandalan sistem dan sarana pelayanan. Responsiveness, yaitu adanya keinginan atau tanggung jawab petugas pelayanan untuk para pelanggan atau masyarakat serta memberikan pelayanan yang sebaik mungkin. Assurance, atau adanya jaminan yang dapat dipahami sebagai pengetahuan dan kesopansantunan para aparat pelayanan terhadap pelanggan sehingga mampu menumbuhkan kepercayaan pelanggan terhadap organisasi pelayanan. Adapun empathy, adalah kemampuan petugas pelayanan dalam memberikan perhatian yang tulus kepada para pelanggan dan memahami kebutuhan pelanggan baik.

Dengan demikian, kualitas perpustakaan perguruan tinggi dapat terwujud jika pustakawan dan para pengelola perpustakaan memperhatikan kelima dimensi tersebut dan memasukkan komponen-komponen yang ada di perpustakaan ke dalam masingmasing dimensi kemudian mengukurnya. Pengukuran tentang kualitas tersebut dapat dilakukan dengan membandingkan antara harapan pemustaka yang dilayani dengan persepsi mereka tentang pelayanan yang dirasakan. Di samping itu, dimensi kualitas tersebut juga dapat diukur dengan mengacu atau berpedoman pada standar baik yang berskala nasional maupun internasional. Standar yang berskala nasional adalah Standar Nasional Perpustakaan yang disusun dan diterbitkan oleh Perpustakaan Nasional

18 Valarie A. Zeithaml, A. Parasuraman, and Leonard L. Berry, Delivering Quality Service: Balancing Customer Perceprions and Expectation (New York: The Free Press, 1990), hlm. 26. 
RI. Pengukuran juga dapat memperhatikan Standar Nasional Indonesia yang diterbitkan oleh Badan Standar Nasional.

\section{Akreditasi Perpustakaan Perguruan Tinggi}

Akreditasi merupakan prosedur yang digunakan oleh lembaga yang berwenang dalam memberikan pengakuan formal bahwa suatu institusi atau seseorang mempunyai kemampuan untuk melakukan kegiatan tertentu. Young menjelaskan pengertian akreditasi sebagai berikut: the accreditation process is designed primarily to encourage the institution with its evaluation of itself and then to validate what the institution says about itself. ${ }^{19}$ Adapun menurut Cahyono, akreditasi adalah rangkaian seluruh kegiatan dalam proses pemberian sertifikat oleh badan/lembaga akreditasi yang kompeten dan terpercaya, sebagai tanda pengakuan formal yang menyatakan bahwa suatu lembaga penilaian kesesuaian (LPK) seperti lembaga sertifikasi (LS Produk/Kompetensi), laboratorium, lembaga inspeksi dsb, telah memenuhi persyaratan baku dan kompeten untuk melakukan kegiatan sertifikasi tertentu. ${ }^{20}$

Menurut Kebijakan Pengembangan Perpustakaan Nasional Republik Indonesia Tahun 2013, akreditasi adalah prosedur yang digunakan oleh lembaga yang berwenang dalam memberikan pengakuan formal bahwa suatu institusi atau seseorang mempunyai kemampuan untuk melakukan kegiatan tertentu. Lembaga yang telah diakreditasi akan mendapatkan sertifikat. Akreditasi perpustakaan merupakan rangkaian kegiatan proses pengakuan formal oleh lembaga akreditasi perpustakaan yang menyatakan bahwa lembaga perpustakaan telah memenuhi persyaratan untuk melakukan kegiatan pengelolaan perpustakaan.

Akreditasi dilakukan oleh pakar sejawat dan mereka yang memahami hakekat pengelolaan perguruan tinggi sebagai tim atau kelompok asesor. Keputusan mengenai mutu atau

${ }^{19}$ Kenneth E. Young, "New Pressures on Accreditation", The Journal of Higher Education, Vol. 50, No. 2, March-April 1979, hlm. 135.

${ }^{20}$ Nur Cahyono, "Prosedur Akreditasi Perpustakaan", disampaikan pada acara Sosialisasi Akreditasi Perpustakaan Badan Perpustakaan dan Arsip DI Yogyakarta, 11 Juni 2014, hlm. 4. 
kualitas didasarkan pada penilaian terhadap berbagai bukti yang terkait dengan standar yang ditetapkan dan berdasarkan nalar dan pertimbangan para pakar sejawat (judgments of informed experts). Bukti-bukti yang diperlukan termasuk laporan tertulis yang disiapkan oleh lembaga perpustakaan perguruan tinggi yang diakreditasi dan yang diverifikasi melalui kunjungan para pakar sejawat ke tempat kedudukan perpustakaan perguruan tinggi tersebut.

Akreditasi perpustakaan perguruan tinggi mengarah pada penyediaan layanan perpustakaan yang bermutu dan kedudukannya dapat ditempatkan sebagai alat regulasi diri (selfregulation) di mana perpustakaan mengenal dan memahami kekuatan dan kelemahannya. Akreditasi perpustakaan adalah sarana untuk melakukan upaya-upaya yang terus-menerus dalam meningkatkan kekuatan-kekuatan yang dimiliki perpustakaan serta memperbaiki kelemahan-kelemahan yang dimiliki. Proses akreditasiterhadap perpustakaan harus sampaipada titikmembuka dan memberikan keyakinan kepada pemustaka khususnya dan masyarakat pada umumnya, di mana perpustakaan telah dan akan melaksanakan berbagai program kerja perpustakaan dengan sumber daya yang dimilikinya baik manusia maupun sumber daya lainnya secara sungguh-sungguh agar terjadi proses pelayanan yang berkualita. Proses akreditasi perpustakaan harus didukung oleh pemahaman yang sama dan komitmen yang kuat semua komponen yang ada baik perpustakaan yang terakreditasi maupun penyelenggara akreditasi.

Penyelenggara akreditasi adalah lembaga independen yang anggotanya terdiri atas berbagai organisasi asosiasi perpustakaan di bawah dan bertanggung jawab kepada Kepala Perpustakaan Nasional RI (c.q. Deputi Bidang Pengembangan Sumber Daya Perpustakaan), salah satu tugas pokok Deputi Bidang Pengembangan Sumber Daya Perpustakaan adalah melaksanakan akreditasi dan memberikan sertifikat terakreditasi kepada organisasi perpustakaan. Tujuan akreditasi perpustakaan adalah untuk mendokumentasikan, menerapkan, dan memelihara sistem 
manajemen mutu secara terus-menerus memperbaiki efektivitas dan berkomitmen untuk melaksanakan sistem manajemen mutu dan mau menjadi lebih baik (continual improvement). ${ }^{21}$ Dengan pengertian yang hampir sama, Nur Cahyono menjelaskan bahwa tujuan akreditasi perpustakaan adalah untuk meningkatkan kepercayaan masyarakat (pemustaka) terhadap kinerja perpustakaan serta menjamin konsistensi kualitas kegiatan perpustakaan yang bersangkutan. ${ }^{22}$

Menurut O’ Brian, akreditasi perpustakaan adalah proses jaminan mutu yang dikendalikan oleh standar, kebijakan, dan prosedur pada sebuah perpustakaan. ${ }^{23}$ Akreditasi perpustakaan merupakan suatu proses dan hasil. Sebagai proses, akreditasi merupakan suatu upaya Perpustakaan Nasional untuk menilai dan menentukan status kualitas lembaga perpustakaan perguruan tinggi berdasarkan standar mutu yang telah ditetapkan. Sebagai hasil, akreditasi merupakan status kualitas perpustakaan perguruan tinggi yang diumumkan kepada masyarakat. Penilaian kualitas dalam rangka akreditasi lembaga perpustakaan perguruan tinggi harus dilandasi dengan standar yang lengkap dan jelas sebagai tolok ukur penilaian tersebut. Di samping itu juga diperlukan penjelasan operasional mengenai prosedur dan langkah-langkah yang ditempuh, sehingga penilaian itu dapat dilakukan secara sistemik dan sistematis. Standar yang dapat dijadikan sebagai pedoman akreditasi perpustakaan terdiri dari beberapa macam, antara lain: Standar Nasional Perpustakaan yang sesuai dan terkait dengan perpustakaan yang bersangkutan (memilih satu dari 10 SNP), Standar Nasional Indonesia (SNI)

${ }^{21}$ M. Solihin Arianto, "Akreditasi Perpustakaan Perguruan Tinggi Menuju Perpustakaan Standar", disampaikan pada acara Workshop Akreditasi Perpustakaan Perguruan Tinggi, Sekolah, dan Umum/Instansi/Desa Yogyakarta, 10 Juni 2014, hlm. 7.

${ }^{22}$ Nur Cahyono, Kebijakan Nasional Pengembangan Perpustakaan Di Indonesia Menuju Perpustakaan Terakreditasi (Jakarta: Perpustakaan Nasional RI, 2013), hlm. 1.

23 Michael O’Brian, Akreditasi Perpustakaan Sekolah (Jakarta: Gramedia, 2010), hlm. 65. 
terkait untuk komponen-komponen yang diperlukan namun belum terliput dalam SNP, standar manajemen sistem mutu dalam kegiatan perpustakaan, pedoman akreditasi perpustakaan terkait dan pedoman-pedoman lain yang dikembangkan (termasuk kode etik asesor, penyusunan laporan penilaian). Menurut Ratminto, setiap penyelenggara pelayanan publik harus memiliki standar pelayanan dan dipublikasikan sebagai jaminan adanya kepastian bagi penerima jasa pelayanan. ${ }^{24}$ Standar pelayanan merupakan ukuran yang dibakukan dalam penyelenggaraan pelayanan yang wajib ditaati oleh pemberi dan atau penerima jasa pelayanan.

Berikut adalah tahapan yang perlu diperhatikan oleh perpustakaan perguruan tinggi dalam kegiatan akreditasi perpustakaan. ${ }^{25}$

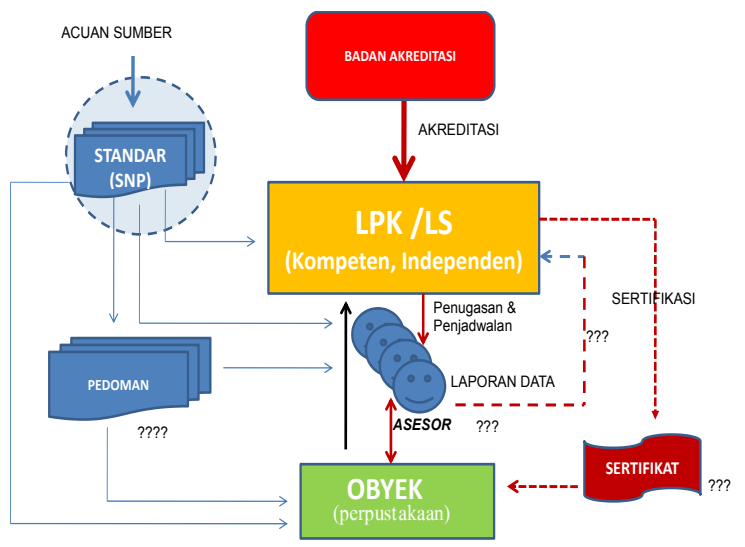

Dari gambar di atas, dapat dipahami bahwa akreditasi perpustakaan perguruan tinggi yang dilakukan oleh badan akreditasi yang ditunjuk itu mengacu pada sumber acuan yaitu standar nasional perpustakaan dan pedoman akreditasi. Oleh karena itu, agar akreditasi dapat memperoleh hasil yang

24 Ratminto dan Atik Septi Winarsih, Manajemen Pelayanan: Pengembangan Model Konseptual, Penerapan Citizen's Charter dan Standar Pelayanan Minimal (Yogyakarta: Pustaka Pelajar, 2009), hlm. 23.

${ }^{25}$ Nur Cahyono, "Prosedur Akreditasi Perpustakaan”, hlm. 6. 
maksimal, perpustakaan perguruan tinggi yang diakreditasi harus memperhatikan komponen-komponen, jumlah indikator kunci, bobot tiap indikator, skor minimal dan skor maksimalnya. Perpustakaan perguruan tinggi sebagai lembaga yang dijadikan sebagai objek akreditasi harus menyiapkan laporan tentang pengelolaan perpustakaan sebaik-baiknya dengan disertai data yang akurat dan akuntabel, serta disertai bukti-bukti fisik yang jelas. Asesor yang ditunjuk melakukan akreditasi pasti akan melakukan verifikasi data laporan dengan bukti-bukti fisik tersebut. Oleh karena itu diharapkan jangan sampai terjadi, laporan kegiatan perpustakaan perguruan tinggi dibuat rapi tetapi tidak disertai dengan bukti-bukti fisik yang memadai, sehingga penilaian akreditasi tidak memperoleh hasil yang maksimal.

Di samping itu, perpustakaan perguruan tinggi yang akan mengusulkan akreditasi perpustakaan perlu memahami prosedur akreditasi berikut ini. ${ }^{26}$

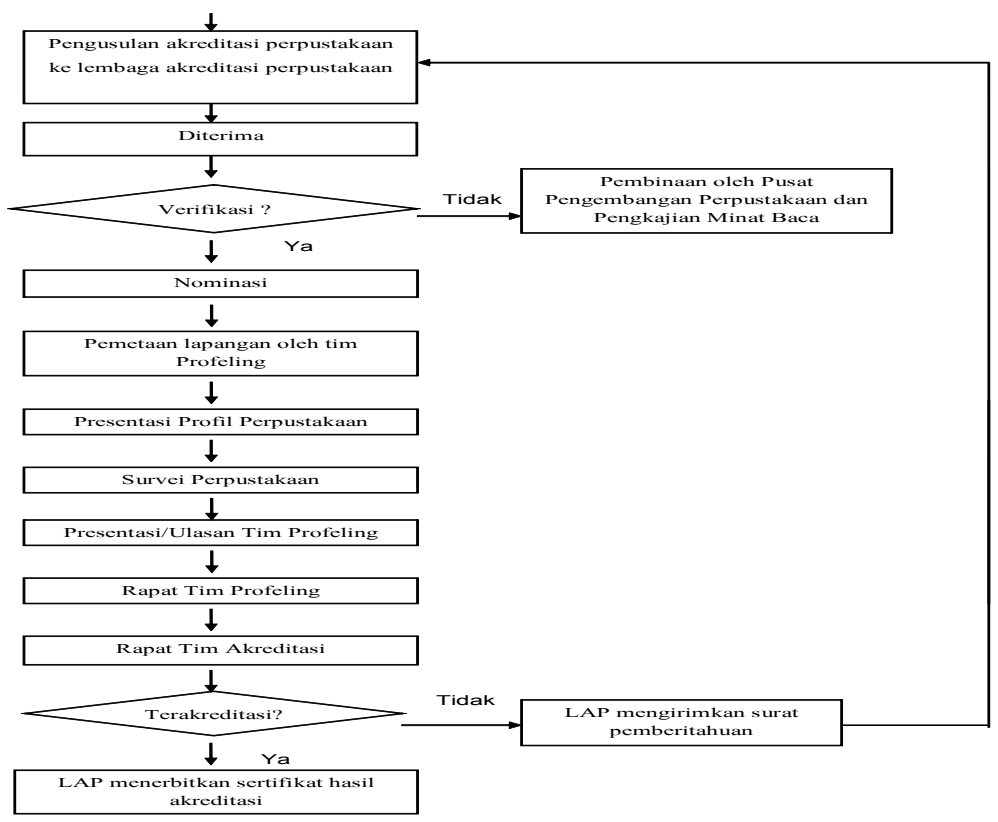

${ }^{26}$ Nur Cahyono, "Prosedur dan Strategi Akreditasi Perpustakaan untuk Meraih Hasil Optimal”, disampaikan pada Seminar Nasional Perpustakaan di Perpustakaan Universitas Islam Indonesia Yogyakarta, 4 Juni 2015, hlm. 25. 
Dari prosedur di atas, dapat dipahami bahwa perpustakaan perguruan tinggi yang akan mengikuti akreditasi perpustakaan harus mengusulkan kepada Lembaga Akreditasi Perpustakaan Nasional (LAPN). Setelah usulan tersebut diterima, Lembaga Administrasi Perpustakaan Nasional kemudian akan melakukan verifikasi terhadap usulan tersebut. Jika hasil verifikasi tersebut dinyatakan lolos maka perpustakaan perguruan tinggi tersebut dinominasikan untuk dilakukan akreditasi. Selanjutnya Tim Profiling akan melakukan pemetaan lapangan dan dilanjutkan dengan presentasi profil perpustakaan. Langkah berikutnya adalah survey ke perpustakaan perguruan tinggi yang mengusulkan akreditasi. Setelah itu dilaksanakan, presentasi atau ulasan oleh tim profiling sebagai hasil survei dan dilanjutkan rapat tim profiling serta rapat tim akreditasi. Hasil dari rapat tersebut akan menentukan apakah perpustakaan perguruan tinggi tersebut dapat terakreditasi atau belum dapat terakreditasi. LAP-N mengirimkan surat pemberitahuan kepada perpustakaan perguruan tinggi yang bersangkutan sesuai dengan hasil penilaian. LAP-N juga akan menerbitan sertifikat hasil akreditasi bagi perpustakaan perguruan tinggi yang telah terakreditasi.

Agarakreditasidapatberhasil baik, perpustakaan perguruan tinggi harus memperhatikan komponen-komponen yang dinilai dalam akreditasi. Berikut ini adalah tabel tentang komponen yang dinilai pada akreditasi perpustakaan berikut bobotnya. ${ }^{27}$

\begin{tabular}{clcll}
\hline No. & & Komponen & Bobot & Keterangan \\
\hline 1 & Layanan & 20 & Aspek Pokok \\
\hline 2 & Kerjasama & 5 & Aspek Penunjang \\
\hline 3 & Koleksi & 15 & Aspek Pokok \\
\hline 4 & Pengorganisasian Materi Perpustakaan & 10 & Aspek Penunjang \\
\hline 5 & Sumber Daya Manusia & 15 & Aspek Pokok \\
\hline 6 & Gedung/Ruang, Sarana Prasarana & 10 & Aspek Penunjang \\
\hline 7 & Anggaran & 10 & Aspek Penunjang \\
\hline
\end{tabular}

${ }^{27}$ Perpustakaan Nasional RI, Akreditasi Perpustakaan Perguruan Tinggi (Jakarta: Perpustakaan Nasioan RI, 2013), hlm. 26. 


\begin{tabular}{|c|c|c|c|}
\hline 8 & Manajemen Perpustakaan & 10 & Aspek Penunjang \\
\hline 9 & Perawatan Koleksi Perpustakaan & 5 & Aspek Penunjang \\
\hline & Jumlah & 100 & \\
\hline
\end{tabular}

\section{Peran Pustakawan dalam Akreditasi Perpustakaan}

Pustakawan secara tradisional terkadang masih dipahami secara umum sebagai kurator buku dan bahan-bahan informasi lainnya, dan sekedar memberikan layanan kepada pemustaka dalam mengakses informasi. Tampaknya pengertian seperti itu tidak tepat lagi bagi pustakawan, sebab jika dicermati betul peran dan tugas pustakawan sangat berat dan menuntut kompetensi yang bermacam-macam. Wilson dan Tauber mengatakan bahwa pustakawan perguruan tinggi yang kompeten merupakan hal yang sangat penting, dan untuk mewujudkan kompetensi pustakawan tersebut dapat melalui pendidikan serta pelatihan sehingga mereka dapat mengorganisasikan sumber-sumber informasi untuk terciptanya pengajaran dan penelitian yang efektif. ${ }^{28}$

Menurut Khoo, kompetensi pustakawan terbagi menjadi bermacam-macam yaitu kompetensi tradisional yang diwujudkan dengan kegiatan teknis seperti akuisisi, katalogisasi dan pelayanan referensi. Di samping itu juga harus memiliki kompetensi yang lain seperti kompetensi di bidang penelitian, kemas ulang informasi, teknologi informasi, soft skills, sikap dan personality, serta pemahaman terhadap subjek yang mendalam. ${ }^{29}$ Kompetensi pustakawan yang bermacam-macam itu sangat dibutuhkan dalam kegiatan akreditasi perpustakaan perguruan tinggi. Menurut penulis, ada bebarapa hal yang perlu diperankan pustakawan dalam kegiatan akreditasi perpustakaan perguruan tinggi, yaitu:

${ }^{28}$ Louis Round Wilson and Maurice F. Tauber, The University Library: The Organization, Administration, and Functions Of Academic Libraries (New York: Columbia University Press, 1966), hlm. 20.

${ }^{29}$ Christopher Soo-Guan Khoo, Competencies for New Era Librarians and Information Professionals (Singapore: Division of Information Studies School of Communication and Information Nanyang Technological University, 2005), diambil pada tanggal 22 Januari 2016, dari http://www.lib.usm.my/elmu. equip/conference/documents/ICOL2005 Paper 2 Christopher Khoo.pdf. 


\section{a. Mempelajari Pedoman Akreditasi}

Di dalam buku Akreditasi Perpustakaan yang diterbitkan oleh Perpustakaan Nasional terdapat sembilan komponen akreditasi seperti yang dapat dilihat dalam tabel berikut ini. ${ }^{30}$

\begin{tabular}{clcc}
\hline No. & Komponen & Jumlah Indikator & Bobot \\
\hline 1 & Layanan & 12 & 20 \\
\hline 2 & Kerja sama & 2 & 5 \\
\hline 3 & Koleksi & 14 & 15 \\
\hline 4 & Pengorganisasian Bahan Perpustakaan & 3 & 10 \\
\hline 5 & Sumber Daya Manusia & 10 & 15 \\
\hline 6 & Gedung/ruang, Sarana Prasarana & 35 & 10 \\
\hline 7 & Anggaran & 3 & 10 \\
\hline 8 & Manajemen Perpustakaan & 5 & 10 \\
\hline 9 & Perawatan Koleksi perpustakaan & 3 & 5 \\
\hline & Jumlah & 87 & $100 \%$ \\
\hline
\end{tabular}

Pustakawan pada perpustakaan perguruan tinggi yang sedang atau akan diakreditasi harus mencermati betul indikator dari masing-masing komponen dan berusaha agar dalam setiap indikator mendapatkan nilai 5 sehingga jika dikalikan 87 jumlah indikator mendapatkan nilai 435. Berikut adalah nilai maksimal masing-masing komponen dalam pedoman akreditasi yang perlu dipelajari oleh pustakawan.

1) Komponen layanan

Untuk komponen layanan, total nilai yang dapat diperoleh adalah 60. Nilai 60 ini diperoleh jika ke-12 indokator pelayanan mendapatkan nilai maksimal yaitu 5. Dalam pedoman akreditasi perguruan tinggi, nilai maksimal untuk pelayanan dapat diperoleh jika perpustakaan perguruan tinggi tersebut: (a) memiliki jam buka perpustakaan per harilebih dari 10 jam; (b) jam buka perpustakaan per minggu lebih dari 48 minggu; (c) sistem peminjaman buku menggunakan sistem otomasi dan manual; (d) persentase jumlah mahasiswa yang menjadi anggota perpustakaan lebih dari $80 \%$;

30 Perpustakaan Nasional RI, Petunjuk Pelaksanaan Akreditasi Perpustakaan (Jakarta: Perpustakaan Nasional RI, 2014), hlm. 10. 
(e) persentase jumlah dosen dan tenaga kependidikan yang menjadi anggota perpustakaan lebih dari $80 \%$; (f) jumlah ratarata buku yang dipinjam per bulan dalam satu tahun lebih dari 6000 judul; (g) jenis promosi yang pernah dilaksanakan (misalnya brosur, lomba, pameran, penyebaran daftar buku terbaru, display buku baru, orientasi, dll.) per tahun lebih dari 8 jenis; (h) jumlah promosi perpustakaan per tahun lebih dari $8 \mathrm{kali}$; (i) pelayanan berbasis teknologi tnformasi dan komunikasi (TIK) menggunakan internet dan intranet; (j) literasi informasi (pendidikan pemustaka, orientasi perpustakaan, dll.) per tahun lebih dari $3 \mathrm{kali}$; (k) otomasi perpustakaan digunakan untuk penelusuran (OPAC), sirkulasi, dan keanggotaan; dan (l) layanan yang diberikan perpustakaan adalah layanan baca ditempat, sirkulasi, penelusuran informasi, bimbingan pemakai dan fotocopy. ${ }^{31}$

2) Komponen kerja sama

Komponen kerja sama pengembangan perpustakaan dapat memperoleh nilai maksimal (10), jika kedua indikatornya mendapatkannilai5, yaitu:(a)jikajumlahkerjasamapengembangan perpustakaan dengan komunitas lingkungan perguruan tinggi (rektor, fakultas, jurusan, pengelola program, pengajar, mahasiswa, lembaga penelitian di perguruan tinggi, dll.) per tahun lebih dari 3 kali; (b) jumlah kerja sama pengembangan perpustakaan dengan komunitas lingkungan di luar perguruan tinggi (perpustakaan nasional, perpustakaan provinsi, perpustakaan umum kab/kota, perpustakaan perguruan tinggi lain, lembaga pemerintah, dll.) per tahun lebih dari 3 kali. ${ }^{32}$

3) Komponen koleksi

Komponen koleksi bisa mendapatkan nilai maksimal (70), jika ke-14 indikatornya mendapatkan nilai 5, yaitu: jika (a) jumlah keseluruhan koleksi buku (cetak) lebih dari 10.000 judul; (b) persentase koleksi inti (koleksi yang menunjang kurikulum program studi) dari keseluruhan koleksi lebih dari

${ }^{31}$ Perpustakaan Nasional RI, Akreditasi Perpustakaan Perguruan Tinggi (Jakarta: Perpustakaan Nasional RI, 2013), hlm. 4-6.

${ }^{32}$ Ibid., hlm. 5. 
80\%; (c) judul buku referens yang dimiliki (misalnya kamus, ensiklopedia direktori, handbook/manual, atlas, globle, dll.) lebih dari 500 judul; (d) surat kabar yang dilanggan lebih dari 4 judul; (e) majalah yang dilanggan lebih dari 4 judul; (f) jumlah jurnal ilmiah yang dilanggan per program studi lebih dari 3 judul per program studi; (g) melanggan jurnal elektronik lebih dari 3 judul per program studi; (h) jumlah koleksi khusus (hasil penelitian, skripsi, tesis dan disertasi) dalam 3 tahun terakhir lebih dari 2000 judul; (i) prosentase penambahan koleksi per tahun lebih dari 16\%; (j) stok opname 1 tahun sekali; (k) penyiangan 1 tahun sekali; (l) survey kebutuhan koleksi dilakukan rutin dengan menyebarkan kuesioner dan wawancara; (m) jumlah sumber daya elektronik lebih dari 2000 judul, (n) website perpustakaan sudah ada kontennya secara lengkap.

4) Komponen Pengorganisasian bahan perpustakaan

Komponen pengorganisasi bahan perpustakaan akan mendapatkan nilai maksimal yaitu nilai 15, yaitu: (a) jumlah alat seleksi bahan perpustakaan (masukan dari pemustaka, timbangan buku, bibliografi, anotasi, katalog penerbit, dll.) lebih dari 7 jenis; (b) pengolahan buku meliputi inventarisasi, klasifikasi, pengatalogan (manual dan otomasi), labelling; dan (c) kelengkapan buku meliputi kartu katalog, kantong kartu buku, slip tanggal kembali, label buku, barcode/chip (sebagai perangkat otomasi).

5) Sumber daya manusia

Komponen sumber daya manusia dapat memperoleh nilai 50 untuk sepuluh indikator, jika: (a) status kepala perpustakaan fungsionalpustakawan;(b)jenjangpendidikankepalaperpustakaan dalam 3 tahun terakhir adalah S3/S2/S1 perpustakaan; (c) jumlah diklat perpustakaan yang pernah diikuti kepala perpustakaan lebih dari 5 kali; (d) continuing profesional development kepala perpustakaan (seminar, pelatihan, lokakarya, bimbingan teknis) 3 tahun terakhir lebih dari 10 kali; (e) jumlah tenaga perpustakaan lebih dari 16 orang; (f) jumlah tenaga perpustakaan yang berlatar belakang pendidikan minimal S3/S2/S1/D3/D2 perpustakaan lebih dari 8 orang; (g) jumlah tenaga perpustakaan berstatus 
pustakawan (fungsional) lebih dari 3 orang; (h) jumlah rata-rata diklat perpustakaan yang diikuti tenaga tetap perpustakaan dalam 3 tahun lebih dari 9 kali; (i) jumlah rata-rata continuing profesional development tenaga tetap perpustakaan (seminar, pelatihan, lokakarya, bimbingan teknis) dalam 3 tahun terakhir lebih dari 11 kali; (j) jumlah tenaga perpustakaan sebagai anggota profesi (misalnya forum perpustakaan, asosiasi tenaga perpustakaan, Ikatan Pustakawan Indonesia dll.) lebih dari 9 orang.

6) Gedung/ruang dan sarana prasarana

Komponen gedung/ruang, sarana dan prasarana dapat memperoleh nilai maksimal 175 jika ke-35 indikatornya mendapatkan nilai 5, yaitu: (a) luas gedung/ruang perpustakaan lebih dari $999 \mathrm{~m}^{2}$; (b) luas area koleksi (45\%) lebih dari $449 \mathrm{~m}^{2}$; (c) luas area baca (25\%) lebih dari $249 \mathrm{~m}^{2}$; (d) luas area untuk staf (20\%) lebih dari $198 \mathrm{~m}^{2}$; (e) luas area lain (10\%) lebih dari $99 \mathrm{~m}^{2}$; (f) lebersihan gedung dan ruangan sangat bersih; (g) pencahayaan sangat terang; (h) sirkulasi udara sangat baik; (i) letak/lokasi perpustakaan di pusat kegiatan pembelajaran dan administrasi PT, (j) keamanan, ada locker penitipan barang, penjagaan petugas, TV monitor CCTV; (k) rak buku lebih dari 19 buah; (l) rak jurnal lebih dari 7 buah; (m) rak surat kabar lebih dari 3 buah; (n) rak multimedia lebih dari 4 buah;(o) Rak buku referens lebih dari 4 buah; (p) laci katalog lebih dari 3 buah; (q) rak display buku baru lebih dari 4 buah; (r) rak penitipan tas (loker) lebih dari 3 buah; (s) jumlah tempat penyimpanan berkas (lemari/filing kabinet) lebih dari 9 buah; (t) jumlah papan pengumuman lebih dari 3 buah; (u) meja belajar perorangan (study carrel), lebih dari 20 buah; (v) meja baca lebih dari 21 buah; (w) jumlah meja sirkulasi (manual dan otomasi) lebih dari 3 buah; (x) jumlah meja kerja petugas lebih dari 16 buah; (y) kursi baca lebih dari 70 buah; (z) kursi tamu lebih dari 3 set; (aa) komputer dan printer untuk kegiatan pengelolaan perpustakaan lebih dari 16 buah; (bb) scanner lebih dari 3 buah; (cc) komputer untuk pemustaka lebih dari 16 buah; (dd) perangkat multi media lebih dari 3 buah; (ee) jumlah mesin tik lebih dari 3 buah 25; (ff) jumlah televisi lebih dari 8 buah; (gg) 
kipas angin lebih dari 8 buah; (hh) kamera lebih dari 3 buah; (ii) AC lebih dari 8 buah.

\section{7) Anggaran}

Komponen anggaran dapat memperoleh nilai maksimal 30 jika ketiga indikatornya mendapat nilai 5, yaitu jika: (a) jumlah anggaran per tahun lebih dari 200 juta rupiah; (b) alokasi anggaran untuk perpustakaan dari seluruh anggaran perguruan tinggi lebih dari $5 \%$; (c) jumlah dana partisipasi masyarakat atau sumbangan yang tidak mengikat lebih dari 100 juta.

8) Manajemen perpustakaan

Komponen manajemen perpustakaan dapat memperoleh nilai maksimal 50, jika kelima indikatornya mendapatkan nilai 5, yaitu jika: (a) kelembagaan perpustakaan (struktur organisasi), struktur organisasi lengkap dan deskripsi tugas; (b) line of commands Kepala Perpustakaan adalah ketika kepala perpustakaan bertanggung jawab kepada pimpinan perguruan tinggi; (c) pendirian perpustakaan merupakan SK pendirian dari menteri; (d) program kerja perpustakaan terdiri dari program kerja jangka panjang, menengah, pendek; (e) laporan kegiatan yang disusun berupa laporan bulanan, semester dan tahunan.

9) Perawatan koleksi perpustakaan

Komponen perawatan koleksi perpustakan dapat memperoleh nilai maksimal 30, jika ketiga indikatornya mendapatkan nilai 5, yaitu jika: (a) cara pengendalian kondisi ruangan dilakukan dengan menjaga temperatur, cahaya, dan kelembaban yang ideal; (b) pembasmian serangga perusak bahan pustaka (fumigasi) dilakukan 1 tahun sekali; (c) jumlah perbaikan bahan perpustakaan (menyampul, menjilid) per tahun lebih dari 150 eksemplar.

Untuk itu, pustakawan harus mempelajari pedoman akreditasi sebaik-baiknya, kemudian mencoba menganalisa kira-kira apakah kesembilan komponen tersebut di atas telah memenuhi standar yang tertinggi dalam pedoman akreditasi atau belum. Para pustakawan tentu saja harus mendiskusikan dengan para pimpinan agar membuat kebijakan serta dapat menfasilitasi 
perpustakaan sesuai dengan kriteria tertinggi pada pedoman akreditasi. Misalnya pada komponen layanan, karena jam buka layanan perpustakaan yang mendapat nilai tertinggi adalah jam buka layanan yang melebihi 10 jam perhari, maka pustakawan dapat mengajukan kepada pimpinan agar membuat kebijakan atau peraturan tentang jam buka layanan perpustakaan dari mulai pukul 08.00 sampai dengan pukul 19.00 WIB. Jika jam buka layanan perpustakaan kurang dari 10 jam perhari, maka tentu saja nilai untuk komponen ini tidak dapat mencapai nilai 5 yang merupakan nilai tertinggi. Begitu pula untuk komponen lain perlu dicermati.

\section{b. Mengumpulkan Bukti-bukti Fisik}

Pustakawan juga perlu bekerja sama untuk menyediakan bukti-bukti fisik pendukung laporan kegiatan dan pengelolaan perpustakaan perguruan tinggi yang alan diakreditasi. Kegiatan ini sangat penting dilakukan karena menjadi rujukan ketika para asesor melakukan visitasi dan verifikasi. Misalnya, dalam komponen kerja sama pengembangan perpustakaan, Jumlah kerja sama pengembangan perpustakaan dengan komunitas lingkungan perguruan tinggi (rektor, fakultas, jurusan, pengelola program, pengajar, mahasiswa, lembaga penelitian di perguruan tinggi, dll.) per tahun lebih dari 3 kali yang memperoleh nilai 5, maka pustakawan harus mengumpulkan bukti-bukti fisik tersebut berupa laporan kegiatan kerja sama perpustakaan dengan lembagalembaga internal terkait, master of understanding, dan lain-lain. Jumlah kerja sama pengembangan perpustakaan dengan komunitas lingkungan di luar perguruan tinggi (perpustakaan nasional, perpustakaan provinsi, perpustakaan umum kabupaten atau kota, perpustakaan perguruan tinggi lain, lembaga pemerintah, dll.) per tahun lebih dari 3 kali ini mendapat nilai maksimal 5. Untuk itu, bukti fisiknya juga perlu dikumpulkan, sama dengan kegiatan kerja sama dengan lembaga internal.

Kegiatan pustakawan dalam mengumpulkan bukti fisik ini bukan pekerjaan mudah karena komponen penilaian akreditasi perpustakaan terdiri dari 9 komponen dan 87 indikator 
kunci. Untuk itu, pustakawan harus mampu bersinergi dengan komponen lain yang ada baik di lingkungan perpustakaan secara khusus maupun juga dengan komponen lain di luar lingkungan perpustakaan. Pengumpulan bukti fisik ini harus dilakukan dengan sistem pembagian tugas, sehingga diperlukan teamwork yang kompak yang dapat diandalkan. Biasanya dalam lembaga pemerintah, tidak terkecuali di perpustakaan perguruan tinggi ini, teamwork bisa berjalan jika ada SK kepanitiannya. Untuk itu perpustakaan harus mengajukan SK kepanitaan akreditasi kepada pimpinan, sehingga pembagian tugas dan koordinasi dapat dilakukan dengan efektif dan efisien.

\section{c. Melakukan Evaluasi Diri}

Seperti yang telah penulis jelaskan bahwa akreditasi perpustakaan perguruan tinggi dilakukan oleh asesor yang ditugaskan dari Perpustakaan Nasional RI atau Badan Akreditasi Nasional, tergantung apakah akreditasi itu merupakan akreditasi perpustakaan perguruan tinggi secara independen atau merupakan bagian dari akreditasi perguruan tinggi. Untuk itu, pustakawan dengan tim yang sudah dibentuk harus berinisiatif melakukan evaluasi terlebih dahulu dengan berpedoman bada borang akreditasi. Evaluasi ini sangat penting dilakukan untuk mengetahui kondisi perpustakaan yang ideal sebelum dinilai oleh tim asesor. Evaluasi yang dilakukan oleh pustakawan tersebut, hasilnya harus segera ditindaklanjuti oleh semua komponen baik dari dalam perpustakaan sendiri, maupun komponen terkait dari universitas yang merupakan lembaga induknya.

Tindak lanjut dari hasil evaluasi diri dilakukan untuk menyempurnakan kelemahan-kelemahan yang masih ada pada perpustakaannya. Dengan demikian, kelemahan-kelamahan atau kekurangan-kekurangan tersebut dapat dilakukan perbaikan secepatnya sebelum akreditasi diikuti. Tentu saja yang diharapkan adalah sebelum kegiatan akreditasi diikuti yaitu dengan mengajukan diri ke lembaga akreditasi, komponen-komponen perpustakaan beserta indikatornya yang akan dinilai dalam proses akreditasi sudah sesuai atau melampaui standar tertinggi. 


\section{d. Melakukan Simulasi Akreditasi}

Pustakawan hendaknya dapat mengagendakan kegiatan simulasi akreditasi. Artinya, para pustakawan mencoba mengadakan percobaan akreditasi dalam perspektif dirinya sendiri dengan mengacu kepada borang akreditasi yang ada. Sebenarnya kegiatan ini hampir sama dengan evaluasi diri. Hanya saja, kegiatan simulasi ini dilakukan dengan menyerupai kegiatan akreditasi, terutama kegiatan verifikasi yang dilakukan oleh asesor pada saat melakukan visitasi ke perpustakaan.

Untuk melakukan kegiatan simulasi ini, semua borang akreditasi sudah disusun beserta bukti-buktinya. Masing-masing bukti fisik dikelompokkan berdasarkan komponen penilaian dan indikator masing-masing. Beberapa orang di antara pustakawan berperan sebagai asesor, sedangkan lainnya berperan sebagai pustakawan perpustakaaan perguruan tinggi yang sedang diakreditasi. Simulasi ini harus dilakukan secara sungguh-sungguh dan cermat, sehingga diharapkan hasilnya tidak jauh berbeda dari kegiatan akreditasi yang sebenarnya. Kegiatan simulasi ini juga diharapkan dapat memperkirakan hasil yang diperolehnya nanti pada saat mendaftarkan perpustakaannya untuk diakreditasi. Berdasarkan pedoman akreditasi dari Perpustakaan Nasional RI, rentang nilai akreditasi seperti yang tertera berikut ini.

\begin{tabular}{cl}
\hline Nilai & \multicolumn{1}{c}{ Predikat Penilaian } \\
\hline $86-100$ & Akreditasi A (Amat Baik) \\
\hline $71-85$ & Akreditasi B (Baik) \\
\hline $56-70$ & Akreditasi C (Cukup Baik) \\
\hline$<56$ & Tidak Terakreditasi \\
\hline
\end{tabular}

Catatan :

Nilai 56 batas minimal keulusan (diakumulasi dari rata-rata semua unsur atau komponen)

Simulasi yang diperankan oleh perpustakaan diharapkan tidak jauh meleset dari perkiraan, sehingga dimungkinkan nilai akreditasi perpustakaan perguruan tinggi akan berhasil dengan baik dan memuaskan. Tentu saja yang terpenting adalah 
pustakawan harus siap pada saat asesor mengunjungi perpustakaan untuk melakukan visitasi dan verifikasi.

\section{Simpulan}

Perpustakaan perguruan tinggi sebagai unsur yang sangat penting dalam mendukung kegiatan tri dharma perguruan tinggi yaitu pendidikan dan pengajaran, penelitian dan pengabdian masyarakat, harus dikelola dengan sebaik-baiknya agar berkualitas. Kualitas perpustakaan perguruan tinggi dapat terwujud apabila dalam pengelolaannya mengacu kepada standar perpustakaan. Salah satu standar minimal di Indonesia adalah Standar Nasional Perpustakaan yang diterbikan oleh Perpustakaan Nasional RI. Implementasi dari standar tersebut perlu dievaluasi baik internal dan eksternal. Akreditasi merupakan salah satu bentuk dari evaluasi eksternal.

Karena akreditasi perlu dipersiapkan dengan baik, maka pustakawan harus berperan secara maksimal. Di antaranya adalah mempelajari sembilan komponen dalam akreditasi, menyiapkan bukti-bukti fisik, melakukan evaluasi diri, dan melakukan simulasi akreditasi perpustakaan. Kegiatan-kegiatan tersebut dilakukan sebelum akreditasi dilakukan. Pada saat akreditasi berjalan, terutama pada saat asesora melakukan visitasi dan verifikasi, pustakawan juga harus mampu menjawab dan menunjukkan bukti-bukti tertulis. 


\section{DAFTAR PUSTAKA}

Arianto, M. Solihin. "Akreditasi Perpustakaan Perguruan Tinggi Menuju Perpustakaan Standar", disampaikan pada acara Workshop Akreditasi Perpustakaan Perguruan Tinggi, Sekolah, dan Umum/Instansi/Desa Yogyakarta, 10 Juni 2014.

Basuki, Sulistyo. Pengantar Ilmu Perpustakaa. Jakarta: Gramedia, 1993.

- Periodisasi Perpustakaan Indonesia. Bandung: Remaja Rosdakarya, 1994.

Brophy, Peter. The Academic Library. London: Facet Publishing, 2006.

Cahyono, Nur. "Prosedur Akreditasi Perpustakaan", disampaikan pada acara Sosialisasi Akreditasi Perpustakaan Badan Perpustakaan dan Arsip DI Yogyakarta, 11 Juni 2014.

- "Prosedur dan Strategi Akreditasi Perpustakaan untuk Meraih Hasil Optimal", disampaikan pada Seminar Nasional Perpustakaan di Perpustakaan Universitas Islam Indonesia Yogyakarta, 4 Juni 2015.

- Kebijakan Nasional Pengembangan Perpustakaan Di Indonesia Menuju Perpustakaan Terakreditasi. Jakarta: Perpustakaan Nasional RI, 2013.

Edward Evans, G., Sheila S. Intner, and Jean Weihs, Introduction To Technical Services. California: Libraries Unlimited, 2011.

Goetsch, D.L. and S. David. Introduction to Total Quality: Quality, Productivity, Competitiveness. Englewood Cliffs, NJ: Prentice Hall International, 1994.

Hernon, Peter and Ellen Altman. Assessing Service Quality: Satisfying The Expectations of Library Customers. Chicago: American Library Assiciation, 1998.

. Service Quality in Academic Libraries. Norwood, New Jersey: Ablex Pubishing Corporation, 1995. 
Hughes, Owen E. Public Management and Administration. London: McMillan, 1994.

Khoo, Christopher Soo-Guan. Competencies for New Era Librarians and Information Professionals. Singapore: Division of Information Studies School of Communication and Information Nanyang Technological University, 2005), diambil pada tanggal 22 Januari 2016, dari http://www. lib.usm.my/elmu.equip/conference/documents/ICOL2005 Paper 2 Christopher Khoo.pdf.

N.S., Sutarno. Perpustakaan dan Masyarakat. Jakarta: Yayasan Obor Indonesia, 2003.

O’Brian, Michael. Akreditasi Perpustakaan Sekolah. Jakarta: Gramedia, 2010.

Perpustakaan Nasional RI. Akreditasi Perpustakaan Perguruan Tinggi. Jakarta: Perpustakaan Nasioan RI, 2013.

. Petunjuk Pelaksanaan Akreditasi Perpustakaan. Jakarta: Perpustakaan Nasional RI, 2014.

Puspitasari, Dewi. "Penjaminan Mutu Perpustakaan Perguruan Tinggi”, Jurnal Perpustakaaan Airlangga (JPUA), Vol. 5, No. 1, Januari-Juni 2015.

Ratminto dan Atik Septi Winarsih. Manajemen Pelayanan: Pengembangan Model Konseptual, Penerapan Citizen's Charter dan Standar Pelayanan Minimal. Yogyakarta: Pustaka Pelajar, 2009.

Rubin, Richard E. Foundations of Library and Information Science.

New York: Neal-Schuman Publishers, 1998.

Sallis, Edward. Total Quality Management in Education: Manajemen Mutu Pendidikan. Yogyakarta: IRCiSoD, 2006.

Stark, J.S. and A. Thomas. Assesment and Program Evaluation. California: Simon and Schuster Custom Publishing, 1994.

Supranto, J. Pengukuran Tingkat Kepuasan Pelanggan, Cetakan Ketiga. Jakarta: Rineka Cipta: Jakarta, 2006.

Tjiptono, Fandy dan Anastasia Diana. Total Quality Management. Yogyakarta: Penerbit Andi, 2003. 
Wilson, Louis Round and Maurice F. Tauber. The University Library: The Organization, Administration, and Functions Of Academic Libraries. New York: Columbia University Press, 1966.

Young, Kenneth E. “New Pressures on Accreditation”, The Journal of Higher Education, Vol. 50, No. 2, March-April 1979.

Zeithaml, Valarie A., A. Parasuraman, and Leonard L. Berry, Delivering Quality Service: Balancing Customer Perceprions and Expectation. New York: The Free Press, 1990. 